\title{
Improving the Quality of Service-Learning Research
}

\section{Emily F Piven}

Associate Professor of Occupational Therapy, College of Health Sciences, university of Texas, USA

${ }^{*}$ Corresponding author: Emily F Piven, OTD, MHE, OTRL Retired Associate Professor of Occupational Therapy, College of Health Sciences, University of Texas at EI Paso, USA, Tel: 915 203-0718; E-mail: emilyh@utep.edu

Rec Date: 09 July 2014, Acc Date: 11 July 2014, Pub Date: 13 July 2014

Copyright: $@ 2014$ Piven E F. This is an open-access article distributed under the terms of the Creative Commons Attribution License, which permits unrestricted use, distribution, and reproduction in any medium, provided the original author and source are credited.

\section{Editorial}

The purpose of this editorial was to review the article, "Examining the Impact of After School Health Education Programming Designed by Undergraduates for Elementary-Age Children" by Sharon $\mathrm{H}$. Thompson, Ed.D., C.H.E.S. and her students [1]. Four undergraduate students, in Dr. Thompson's community-based health education course, conducted a needs assessment with selected staff at a Title 1 elementary school in the Southeastern United States. Then, students collected demographic and anthropometric measurements and administered a pre-test survey, from nineteen, 3rd through 5th grade children. From the needs assessment, the undergraduate students developed an intervention program and executed the program for six weeks, under the guidance of their professor. Then, the students collected post-test data by repeating all measures.

This service-learning program facilitated engagement of undergraduate health education students in every aspect of a research project. As any progressive university professor would do, Dr. Thompson efficiently utilized her time with students to establish a service-learning experience, which at same time created an opportunity for her research and subsequent publication.

Evidence- based practice originated in the field of medicine in 1992 in order to provide a team approach to the systematic selection and appraisal of the best available and most current valid research in a field, thus enabling critical thinking and decision-making of health practitioners [2]. The concept of evidenced-based practice swept the fields of psychology, nursing, occupational therapy, physical therapy, speech and language pathology, dentistry, health education, and other disciplines, in order to identify the best available information upon which to make clinical decisions. Further, evidence-based practice formed the basis for reimbursement by insurance companies to authenticate that goals for clients/patients could be achieved. To evaluate the quality of research, evidence was then organized accordingly, ranging from the weakest to strongest evidence. The lowest level was single-subject group or case study. The highest level design used randomized control trials.

In this study, the one group pre-test, post-test design was completed on nineteen, 3rd-5th graders. To determine the effect of the student group intervention on participants, the professor compiled the Physical Activity, Nutrition, and Hygiene Survey that "was designed to measure knowledge, attitudes, and social norms in these areas, as well as provide demographic information" [1, p.1]. The first author acknowledged that survey items were adapted from several tools $[1, \mathrm{p}$. $1]$.

The Physical Activity, Nutrition, and Hygiene Survey used a 5-point Likert scale that may have addressed the lowest reading level (3rd grade). Flesch-Kincaid grade level determinations have been built into MS-word [3]. The survey questions appeared to target content areas for "skill building" [1.p.1] such as, knowledge about the health benefits of nutritional choices, confidence to ask for healthy food, and appreciation of the health benefits of physical activity. Demographic information by gender, race and age was described. Anthropometric measurements collected were significant at the $p<0.05$ and the mean and standard deviations were reported. $\mathrm{P}$ values for the grouped survey items were significant at $\mathrm{p}<0.05$.

Research can only be as good as the instrument used to measure a phenomenon. Dr. Thompson gathered material from various tools that she anticipated would apply to her target group and context. All of the items on the surveys and questionnaires were designed for different target populations, yet only one questionnaire was standardized. For example, the Healthy Nutrition Education Survey (NHES) was designed for children of people who received food stamps in California. Items composing the NHES came from five different surveys that had been previously published [4-10]. Yet, standardization for the Healthy Nutrition Education Survey and the Personal Hygiene Survey could not be identified online, which did not necessarily mean that it was not available somewhere. The second source of items was the Personal Hygiene Survey, derived for children in Bangalore, India [11]. The third source, the Eat Well, Be Active Nutrition Questionnaire, was a standardized questionnaire for Australian 5th to 7th graders to prevent obesity. The Australian survey actually provided a good example of how to standardize a nutrition assessment on 100 children [12].

Standardized questionnaires should only be used with the population for which they were standardized. For example, Australian elementary school children in the 5th through 7 th grades would be different from 3rd-5th grade children living in a Southeastern costal community in the United States. It would be important to ask and specify the permission to use a tool, unless permission was clearly granted on the tool itself, in a publication, or on a tool website, and free access should be noted. Dr. Thompson did not report that she had been given permission from the various survey authors to restate or use material in her new survey that she intended to research and publish.

Assuming that Dr. Thompson had obtained permission from authors to paraphrase items or use items verbatim, the next step would have been to select a target population upon which to pretest the composite survey, being sure to find a large enough representative sample of both sexes and races before using the survey to gather data with intervention study participants. Typically, authors streamline consistent procedures for administering the tool and making observations. Authors would provide description of how any copy written materials could be used, with whom the survey should be given and in what setting, identify necessary timing, and scoring, in order to control the interference of external factors and assure validity of the information obtained with a standardized test [13]. Statistical analysis 
Page 2 of 2

would identify the items that were found to be statistically significant to be used in the tool and statistically insignificant items to be discarded. Following the preliminary work, then the survey could be used for research and yield data that could be generalized. Further, without determining reliability measures such as test-retest or validity measures such as content validity, concurrent validity, predictive validity, criterion validity, or internal validity, Dr. Thompson found that the elementary students were more self-efficacious "regarding asking parents to choose and prepare fruits and vegetables" [1, p.4], but the construct was not based on concurrent validity with statistically significant tools.

Standardizing a tool may not have been Dr. Thompson's intention. In this case, single subject research comparisons may have been a better way to determine the effect of a service-learning intervention, using graphs to show pre-test/post-test results on criterion-based measures.

Providing challenging opportunities for service-learning requires extra work for a professor, but there are big benefits for students. Students in this study had an opportunity apply health education principles to real people in real settings. The experience was intended to activate critical thinking, group decision-making, teamwork, and the development of presentation and interaction skills among students. The feedback obtained through the measurement of the outcomes of their efforts with the children, may become indelible in the minds of the students and plant the seeds for growth of future health education researchers. Bravo, Dr. Thompson!

Standardization of the Physical Activity, Nutrition, and Hygiene Survey for children in Title 1 elementary schools would provide validation of a tool and improve the quality of the research. Advantages would be to 1) determine the statistically significant items at 3rd, 4th, and 5th grade levels; 2) target the items for the lowest reading levels for each grade, so that it would not be necessary to read to children taking the survey; 3) provide Dr. Thompson with a line of research that could allow her to determine best evidence-based practice for health education of children in title one elementary schools; 4) and enable evaluation of student interventions in multiple service-learning contexts for years to come, which would provide Dr. Thompson with ongoing standardization data for the tool.

\section{References}

1. Thompson SH, Po MC, Reeves JD, Roach KB, Wade LC (2013) Examining the impact of after school health education programming designed by undergraduates for elementary-age children. J Nutr Disorders Ther 3: 126.

2. http://en.wikipedia.org/wiki/Evidence-based_practice.

3. Elliott JO, Shneker BF (2009) A health literacy assessment of the epilepsy.com website. See comment in PubMed Commons below Seizure 18: 434-439.

4. http://www.cdph.ca.gov/programs/cpns/Documents/Network-REUBackgroundforNES-2007-2008.pdf.

5. Vereecken CA, Van Damme W, Maes L (2005) Measuring attitudes, selfefficacy, and social and environmental influences on fruit and vegetable consumption of 11- and 12-year-old children: reliability and validity. See comment in PubMed Commons below J Am Diet Assoc 105: 257-261.

6. Baranowski T, Davis M, Resnicow K, Baranowski J, Doyle C, et al. (2000) Gimme 5 fruit, juice, and vegetables for fun and health: outcome evaluation. See comment in PubMed Commons below Health Educ Behav 27: 96-111.

7. Reynolds KD, Yaroch AL, Franklin FA, Maloy J (2002) Testing mediating variables in a school-based nutrition intervention program. See comment in PubMed Commons below Health Psychol 21: 51-60.

8. Hearn DH, Baranowski T, Baranowski J, Doyle C, Smith M, et al. (1998) Environmental influences on dietary behavior among children: availability and accessibility of fruits and vegetables enable consumption. J Health Edu 29: 26-32.

9. Thiagarajah K, Bai Y, Lo A, Leone A, Shertzer JA, et al. (2006) Assessing validity of food behavior questions from the School Physical Activity and Nutrition Questionnaire. J Nut Ed Beh, 38: S55-S55.

10. Prochaska JJ, Sallis JF, Long B (2001) A physical activity screening measure for use with adolescents in primary care. See comment in PubMed Commons below Arch Pediatr Adolesc Med 155: 554-559.

11. http://www.schools.indiawaterportal.org/sites/ schools.indiawaterportal.org/files/hygiene\%20survey.pdf.

12. Wilson A, Magarey A, Mastersson N (2008) Reliability and relative validity of a child nutrition questionnaire to simultaneously assess dietary patterns associated with positive energy balance and food behaviours, attitudes, knowledge and environments associated with healthy eating. Int J Behav Nutr Phys Act. 5: 5.

13. http://www.natd.org/Code_of_Professional_Responsibilities.html. 